\title{
KONINKRYK EN KERK
}

Die pas verskene Eeufeespublikasie: „Die koninkryk van God”, onder redaksie van prof. $S$. du Toit e.a. kon ek nie volledig raadpleeg nie. Nietemin waag ek my aan die vererende opdrag om oor hierdie onderwerp te praat, omdat die onderwerp aktueel geword het in heel praktiese situasies soos bv. in die verhouding van kerk en universiteit, roeping in kerk en op sekulêre terreine, ens.

Tradisioneel loop die vraag na die verhouding van koninkryk en kerk uit op 'n vraag na terreine, sfere, gebiede of kringe. Ek wil net losweg die vraag stel: Het Kuyper met sy „Calvinisme” en nadruk op soewereiniteit in eie kring (versterk deur die filosofie van ,wetskringe") net goed gedoen? Weliswaar het dit aan die einde van die vorige eeu 'n geweldige oplewing in Nederland veroorsaak - Doleansie, Vereniging met Christelik Gereformeerdes, Vrye Universiteit, Kuyper premier van Nederland, teoloë en publikasies van formaat. - Is dit egter verkeerd om te beweer dat hierdie geweldige aktiwiteit ten diepste gedra was deur 'n kerk. volk wat kerk wou wees? Gaandeweg word die kringe filosofies uitmekaar gehaal - kerk, skool, staat, maatskappy. Kan die kerk summier met ander „kringe” vergelyk word? Is dit nie ook so dat hoe meer die oorspronklike beweging gesekulariseer is, hoe meer het dit innerlik mat en sy doelbepaaldheid verloor nie, sodat dit in baie opsigte vandag op sommige. "terreine" sekularisties, post-Gereformeerd en moontlik selfs post-Christelik mag voorkom nie?

$\mathrm{U}$ moet my vergun om dalk meer vrae as oplossings by $u$ op te roep. Ek het die artikel van prof. S. C. W. Duvenage: „Die verhouding van kerk en koninkryk" in bogenoemde Eeufeespublikasie wel gelees. Ek glo dit gee die heersende beskouing oor die onderwerp goed weer. Nogtans bevredig dit my nie, hoofsaaklik omdat koninkryk en kerk as betreklik abstrakte begrippe en as soortgelyke, naasmekaar-staande groothede vergelyk word en die (valse?) probleemstelling saamtrek in 'n poging om die "terreine" nie te identifiseer of volkome te differensieer nie. Dit is opmerklik dat Luther en Calvyn (en Augustinus) tot identifikasie geneig het (a.w., p. 116, maar let wel hulle verbind koninkryk aan ,regeer deur Woord en Gees'). Voorstanders van gesekulariseerde kerkbeskouinge het weer differensiasies voorgestaan (a.w., p. 115 v.). 'n Definisie van begrippe is seker essensieel om nie by mekaar verby te praat nie.

\section{Definisie van koninkryk en kerk}

a. Die begrip ,koninkryk"

Dr. Tjaart van der Walt sê: „Direk tref die veelsydige betekenisskakering van die uitdrukking". Hy waarsku teen sisteemdwang of oorvereenvoudiging. "Die koninkryk is iets wat kom, en wel tot mense (ek onderstreep, B.S.) - maar dis ook iets waartoe mense 
kom en ingaan en terselfdertyd ook 'n plek of 'n ,sfeer'... Grondleggend is egter deurgaans die gedagte van heilryke soewereiniteit van God, in die eerste plek as daad (koningskap, koningwees), tweedens as terrein (koninkryk, gebied waaroor en waarin die heerskappy uitgeoefen word) en derdens nog inhoudeliker: wat in hierdie almagsuitoefening in hierdie magsfeer gebeur en ontvang word".' Laat ons die kerk vir een oomblik reeds as mense (gelowiges) voorstel - hoe gaan jy kerk en koninkryk dan ooit naasmekaar stel in 'n vergelyking? Dit lyk selfs nie moontlik om die gedagte van koninkryk, gebied, sfeer, anders as 'n magsfeer onder mense voor te stel nie. Hoewel God oor Satan en die skepping regeer, kan „, die wêreld" in hierdie bedeling tog nie met die koninkryk van God (as gebied) geïdentifiseer word nie.

Die gedagte aan 'n ruimtelike ,koninkryk" is egter gevaarlik, omdat in die N.T. „,koninkryk" die gedagte van heerskappy, regeermag, koningskap voorop staan." „Erneut würde deutlich, dass die wesenliche Bedeutung nicht Reich sondern Herrschaft ist. Und damit würde zusammenhängen dass solche Himmelherrschaft ihrer Natur nach nicht ein Reich darstellen kann, das durch eine naturliche Entwicklung irdischer verhältnisse oder durch menslichen Anstrengengen zustand kommt, sondern durch ein Eingriffen Gottes vom Himmel her". Augustinus vind die koninkryk nie in menslike samelewingsverbande nie, behalwe in so ver die ryk in die universele kerk van die tyd aanwesig is.'

Die koninkryk word dus nie hier en nou sonder meer in 'n gebied of op 'n terrein, vergestalt nie, maar ,het koninkrijk nog veelzins schuilgaat... Dit komt met name uit in het feit, dat thans op aarde het eigenlijke rijksgebied nog ontbreekt, daar deze aarde en het gansche leven dezer schepping niet in eigenlijke zin tot het koninkrijk kunnen worden gerekend". Die koninkryk van God in sy volkomenheid is ,niets minder dan eene gansch vernieuwde wereld met eene... vernieuwde menschheid":

\section{b. Die begrip kerk}

Ons bely die universele kerk in koninkrykstaal as ,'n heilige vergadering... van almal wat waarlik in Christus glo... Hierdie kerk... sal daar wees tot aan die einde toe, soos daaruit blyk dat Christus 'n ewige Koning is wat nie sonder onderdane kan wees nie ..." (Art. 27 N.G.B.). Hierdie kerk word in die plaaslike geïnstitueerde kerk openbaar onder Jesus Christus as die enigste algemene Opsiener en Hoof van die kerk wat regeer deur sy Woord en Gees (Art. 28-32 N.G.B.). Hiermee word, soos Calvyn reeds aangetoon het, die onsigbare kerk nie net so op die sigbare gepas nie. In so ver daar hipokriete in die kerk is, is die kerk wyer as die koninkryk, omdat die hipokriete hulle nie aan Christus se heerskappy onderwerp nie. Hulle is wel in die kerk (sigbare), maar nie van die koninkryk (as heerskappy) nie. Duvenage gaan egter uitsluitend daarvan uit dat die koninkryk ruimer is as die kerk (a.w., p. 122, 128). 


\section{Die gebruik van „koninkryk” en ,kerk” in die Skrif}

Die woord koninkryk word in die vier evangelies meer as honderd maal en in die orige N.T. skaars dertig maal gebruik. Daar. teenoor word gemeente (kerk) in die evangelies slegs twee maal (Matth. 16, 18) en in die orige N.T. meer as honderd maal gebruik. Nietemin kom basileia en ekklesia in nou verband met mekaar by Mattheüs voor. Dit dui m.i. reeds daarop dat daar 'n organiese saamhang, 'n sekere gaan van die een begrip na die ander is. Schweitzer dink selfs dat ekklesia by Mattheüs maar basileia beteken."

Hierdie feit het by liberale teoloë egter die idee gewek dat Jesus nooit die kerk bedoel het nie. Hy het die koninkryk gepreek en toe stig sy dissipels, toe die Wederkorns uitbly, die kerk! Bultmann betwyfel, sonder goeie gronde, weer die egtheid van Matth. 16 en 18 . $^{\circ}$ Kattenbusch e.a. sluit egter aan by Dan. 7 en dan volg „De kerk is maar niet een sociologisch verschijnsel, uit de wil der menschen voortgekomen, maar is de noodzakelijke openbaring van het messiaanse volk"."

Die enkele ekklesia-uitsprake van Jesus moet dus gelees word saam met begrippe soos kudde, skape, lammers (bv. Matth. $26: 31$, Joh. $10: 16$, Luk. $12: 32$, Joh. $21: 15,16)$. Die vergadering van die kerk het begin met die roeping van die eerste dissipels." M.i. kan die weinig direkte kerk-uitsprake by Jesus verklaar word uit die feit dat $\mathrm{Hy}$ toe nog binne die kerk van die O.T., die huis van Israel, opgetree het. Hy wou die andersoortige koningwees teenoor die Jode se koningsverwagting eers beklemtoon en nadat die Jode Hom finaal verwerp het, kom die kerk as andersoortige volk of gemeenskap in die volle gesigsveld.

Dit lyk my derhalwe die aangewese weg om die verhouding koninkryk-kerk te verklaar vanuit die begrip volk van God, wat O.T. en N.T. saambind en waarin Jesus Christus as Messias sentraal staan - soos wat Hy ook sentraal in sowel die koninkryk as die kerk staan. J. C. Coetzee sê dat die O.T. die histories-etniese koninkryk en die N.T. die suiwer-godsdienstige koninkryk in die volksgedagte dra. ${ }^{10}$

\section{Die begrip ,volk van God' i.v.m. koninkryk en kerk}

H. Ridderbos sê dat ekklesia in Matth. 16 : 18 „de betekenis heeft van het door de Here Zich verkoren en afgezonderde volk in zijn eenheid en saamvergadering ... Godsvolk, Verbondsvolk. Jezus spreekt hier dus van zijn gemeente, zijn volk, zonder daarmee nog een bepaalde of ook zelfs algemene organisatie aan te duiden ..." Die gemeente sou op die toekomstige apostoliese werksaamheid gebou word." (Is dit nie ons moderne probleem dat ons weer kerk sê en slegs die organisasie bedoel en die volk van God totaal vergeet nie?) Nietemin impliseer Jesus die sigbaarheid van die kerk met die "sleutels van die hemelryk" wat die lyn trek tussen wie in die koninkryk ingaan en wie nie ingaan nie." So ver dit mense betref, is die kerk dus inderdaad ruimer as die koninkryk. 
Volgens J. C. Coetzee word vandag algemeen erken dat Godsvolk die wesensnaam van die kerk is." Dit. dui die volk aan wat die verkiesing van God in 'n absoluut eensoortige posisie geplaas het. Laos dui sowat 18 keer in die N.T. die kerk van Christus aan en wel as gelowiges uit die heidene (Hand. $15: 14$ ); die plaaslike kerk (Hand. 18: 10); die universele kerk (Hebr. 4:9) en die nuwe mensheid, die verheerlikte kerk (Openb. 21 : 3)." Wanneer 'n mens die konotasie van Godsvolk vergelyk met dié van ekklesia in die 112 plekke waarin laasgenoemde voorkom vir of die universele of die plaaslike kerk ${ }^{15}$ is die sinonieme betekenis duidelik.

„Laos dui die gelowiges aan as 'n wesenlik verskillende en eensoortige groep teenoor die ongelowiges; druk die teenstelling van kerk tot wêreld uit - die gelowiges se andersoortigheid - vgl. ook Tit. $2: 12-14,2$ Kor. $6: 14-17$, Openb. $18: 4$ ". "Die wese van die kerk skuil dus in die begrip Godsvolk, wat van Genesis $6: 2$ na Openb. 21 : 3 deurloop.

In Godsvolk het ons egter 'n suiwer koninkryksbegrip! Volk van 'n koning, volk van en vir 'n koninkryk. Dit laat slegs een gevolg. trekking toe: die kerk is lokaal, universeel en esgatalogies die volk van die koninkryk. So kan ons ook bely dat die Seun van God vir hom 'n gemeente deur sy Woord en Gees, vergader, beskerm en onderhou (Kat. Son. 21) en ons moet bid: „Regeer ons so deur u Woord en Gees dat ons hoe langer hoe meer ons aan u onderwerp; bewaar en vermeerder u kerk..." (Sond. 48).

In so ver die koninkryk aanwesige heerskappy en die kerk gelowige mense is, is die kerk gerealiseerde koninkryk, want t.o.v. die werking van die koninkryk buite die kerk, is die heerskappy gerigsmatig: „,vernietig die werke van die duiwel en alle heerskappy (koninkryk, B.S.) wat hom teen u verhef ... totdat die volkomenheid van u ryk kom..." (Son. 48).

\section{Karakter van koninkryk en kerk}

Ek meen dat daar ook 'n duidelike parallel in die karakter van koninkryk en kerk opgemerk kan word. Omdat koninkryk basies heerskappy en nie huidige aardse sfere nie beteken, kom die parallel nie neer op identifikasie of differensiasie nie. Die differensiasie is vir my basies gegee in die verskillende begrippe: koningskap (koninkryk) en Godsvolk (kerk). Die begrippe vra egter om op mekaar betrek te word: koning en volk, terwyl die lokaliteit (gebied) 'n ander aspek van die koninkryk vorm, nou en hiernamaals.

(a) Teosentries: „Basileia vorerst nur das Sein, das Wesen den Zustand des Konigs bezeichnet... seiner Würde seiner Gewalt"." Die koninkryk van God is die koninkryk van Jesus Christus. Ongelowiges het daar geen deel aan nie (Ef. $5: 5$ ). ${ }^{18}$,Immer geht es um das vielfältige und doch ganz eindeutige Sein und Handeln Gottes und um seinen Ruf und Anspruch an die Menschen. Die Menschen sollen suchen das Gottesreich und seine dikaiosunê". Dit is t.o.v. die handeling van God met die mense soteriologies."

Reeds in die O.T. val die besondere koningskap van God (teo- 
krasie) saam met die Verbond en is onderskeie van sy koningskap in die skepping. God handhaaf sy teokrasie in en deur die Messias oor Israel en die wêreld. Die koninkryk is die „koninklijke zelfhandhaving van God". Terwyl die Social Gospel verwag dat mense die koninkryk maak, is dit in wese geen immanent-aardse ontwikkeling nie, maar iets om van God te bid en te verwag. „Het koninkrijk der hemelen is daarom volstrekt trancendent van oorsprong, het is de openbaring van de heerlijkheid Gods...".

(ii) Die kerk is ook teosentries, want die kerk is vrug van die koninkryk. Tog is die koninkryk sonder die kerk ondenkbaar." H. Ridderbos sê ,,dat een van die voornaamste gestalten waarin het koninkrijk in deze wereld optreedt, de prediking van het evangelie is". (Die omgekeerde is dus ook waar: die koninkryk is ook vrug van die kerk in so ver die kerk die evangelie uitdra. In wese is dit egter dieselfde, primêre oorsaak vir koninkryk en kerk, naamlik die Woord en Gees van God, wat vrugte werk.) Die gevolg van die prediking van die evangelie is ,de ingang van het koninkrijk der hemelen in deze wereld", vgl. gelykenisse van die Saaier, onkruid, visnet, selfgroeiende saad, mosterdsaad en suurdeeg." Die koninkryk bring 'n verandering in die lewe van diegene wat dit ontvang, „dat het een daad Gods tot een gave, bezit, levensgebied wordt van degenen aan wie dit voorrecht te beurt valt"." Dit is mense wat die koninkryk ingaan. Hulle is die kerk wat in die sfeer van die koninkryk as 'n gemeenskap op God gerig, as Godsvolk, bestaan.

„De basileia is het grote goddelijke heilswerk der vervulling en voleinding in Christus; die Ekklesia is het door God verkoren en geroepen volk dat in het heil der basileia mag delen. Logisch gaat niet de ekklesia maar de basileia voorop. Zij heeft een veel wijdere inhoud. Zij vertegenwoordigt het alomvattende gezichtspunt", terwyl die kerk net die Godsvolk omvat. ${ }^{2}$ Nietemin word die teosentriese karakter van die kerk uit die koninkryk ontleen. Selfs die vrugte van die kerk is op sy beurt organies verbind aan die koninkryk, vgl. Matth. 21 : 43: „Die koninkryk sal van julle weggeneem en aan ' $n$ volk gegee word wat die vrugte daarvan sal dra". (Vgl. hier kom koninkryk en volk (kerk) ook in een verband voor, B.S.).

Die Skrif ken nie 'n kerk wat antroposentries is nie. Individualisme en enige ,Menscheitsideal ist Jesus und seinen Aposteln fremd"." Tereg grond Calvyn dan ook in die eerste hoofstuk van die vierde boek van die Institusie die kerk in die raad, die uitverkiesing van God en die inwendige roeping deur God. Dit gaan om 'n volk wat op God gerig is, kinders in betrekking tot hulle Vader, d.w.s. teosentries. Ek wil opmerk dat art. 29 N.G.B. die ware kerk dan ook bely as die kerk binne die heerskappy (koninkryk) van die Woord, vry van alle menslike insettinge en goeddunke. Prof. W. J. Snyman haal Kattenbusch met instemming aan: „Die glaubigen im Sinne der Urkirche stufen nicht die Kirche durch zusammentreten als gleichberechtigten Menschen, sondern ,fanden sie vor', ,traten in sie ein'. Nicht die Individuen sind die Konstituante der Kirche; vielmehr ist die Kirche jedem eine Vorangegebentheit, eine tranzendentale su- 
pranaturale Gemeinschaft, für die Menschen als Einzelne von allen Anfang eine ,vorhandene' Stiftunggeistlich (himmlischer) Art". Vandaar kom die begrip van inenting in die kerk (Rom. $11: 19,23$ )." Johannes die Doper roep Israel tot bekering omdat hulle „de bizondere relatie tot God", die teosentriese karakter, verloor het." Hulle moet 'n „toebereide volk vir die Here" wees, terwyl hulle onderlinge saamhorigheid "sekondêr" is." Gelykenisse soos dié van die groot maaltyd karakteriseer die kerk as ,in Godsverkiezing rustende Godsvolk", bepaal deur die verbondsrelasie." Dit is immers dié wat vir God gehoorsaam, tot God gaan, wat volk van God, gemeente van God, tempel van God, akker van God, is. Hierdie teosentriese karakter bepaal die wese van die kerk.

(Hierdie wesensverskil van die kerk met enige menslike „kring”, „terrein", soos skool, staat of maatskappy, kan ons nie Duvenage se voorstelling met konsentriese sirkels (a.w., p. 128) laat aanvaar nie. Dit is heterogene groothede.)

b. Messiaans. (i) Die koninkryk is messiaans en korreleer met Dan. $7: 13$ v., die Seun van die mens, aan wie die heerskappy en koningskap gegee word, 'n heerskappy wat alle volke omvat en ewige onverganklike betekenis sou hê, sodat die koms van Jesus Christus, die Messias, ook die koms van die koninkryk is."

(ii) Die kerk is ook Christosentries (messiaans). Dit is die kerk van Christus (Rom. 16: 16). Hy is gegee as „,Hoof bo alle dinge aan die gemeente... wat sy liggaam is, die volheid van Hom wat alles in almal vervul" (Ef. $1: 22,23$, vgl. Kol. $1: 18$ ). Ridderbos stem met Oepke saam dat "tot het rijk Gods behoren een gemeente, een rijk-Gods-gemeente", wat Hy my gemeente (Matth. 16) noem," sy volk (Matth. 1:21) en sy koninkryk (Matth. 13:41). By Paulus ,,is die universele kerk van gelowiges in die messiaanse hede die messiaanse Godsvolk"." $\mathrm{Na}$ ' $\mathrm{n}$ indringende eksegetiese studie van die begrip „Israel” konkludeer Coetzee: „Die messiaanse Godsvolk is die kerk van Christus - 'n suiwer godsdienstige entiteit van universele omvang waarvan die enigste grens die skeiding tussen gelowiges en ongelowiges is. Daar is vir die messiaanse Godsvolk geen natuurlik-volkse begrensing tot die volk Israel meer nie...".

Die kerk is regstreeks instrument van Christus, soldate-mag van die Christus-koning en sit op aarde voort wat ,met die vleeswording van Christus begin is". In die doopbevel van Matth. 28:19 met sy ,leer hulle om alles te onderhou" ontvang die kerk ook 'n omvattende opdrag om die hele lewe (elke kring en terrein) te bekeer en te reformeer, sodat die kerk as Godsvolk vrugte in die gewone lewensverbande afwerp. Ridderbos haal selfs $\mathrm{K}$. Barth met instemming aan wat sê dat die dissipelskap (ekklesia) selfs vir die volke-eksistensie betekenis kan hê. ${ }^{34}$ Die vrugte van die kerk sal neerkom op die vestiging van die koninkryk waar nasies hulle laat leer om die bevele van Christus, wat met sy kerk tot aan die voleinding is, te gehoorsaam (Matth. $28: 20$ ). ${ }^{*}$

Waar die kerk waarlik kerk is, rus sy regering op hierdie praesentia realis Christi, hier en nou in sy kerk, universeel en lokaal. ${ }^{\text {,n }}$ 
Daarom mag die begrip „kerk" nie tot 'n terrein beperk word nie. "In de Heilige Geest, die ons tot getuigen maakt, openbaart zich dus thans het koninkrijk Gods hier op aarde": Dit is Rooms om te redeneer "ubi papa ibi ecclesia" en die kerk te beperk tot sy amptelike dienste. Veel eerder is die kerk daar waar 'n gelowige hom op elke lewensterrein as ekklesia-lid, as Godonderdaan, as gesant van Christus, openbaar deur wie sy Woord en Gees koninklik en heersend uitgaan. Die gelowige van huis, skool, universiteit, bedryf (vgl. Duvenage: a.w., p. 128) ontleen dan egter op al hierdie terreine sy locus standi aan die Godsvolk (kerk) en die heerskappy (koninkryk) van Christus in hom.

Prof. Snyman benadruk dat Christus sy volheid in die gelowiges en in hulle in al hulle lewensbetrekkinge stort, vgl. Ef. 4 tot 6 . „Die noodsaaklikheid waarom die kerk moet optree op aarde lê hierin dat die organiese lewe van die menslike geslag moet wedergebore word... Die kerk staan in organiese saamhang met die lewe. Dit is die volk van God op aarde ,mit Aufgaben, Kraften, ja auch Betätigungen in der Welt, d.h. ausserhalb ihrer Versammlungen... (Kattenbusch)"."s

Te veel word vergeet in die georganiseerde voorkoms van die kerk en by die institutêr-beperkte kerkbegrip, dat Christus nooit magte na die kerk in amp (Rome) of in vereniging (kollegialisme) gedelegeer het nie en selfs die ampsdraers bly in ware kerkregering blote gereedskap van Christus, omdat Hyself met sy Woord en Gees regeer. „Dit gaan in die Christusregering ook om die korrelasie tussen 'n daad van Christus en die geloofsgehoorsaamheid van die kerk"." "Niet alles wat in Christus naam geschiedt, wordt door Hem aanvaard en bekrachtigd" (Matth. $7: 22$ )."

Die kerk as Godsvolk (en nie 'n blote instituut nie) is diensbaar aan die deurbraak van die koninkryk van die Messias in alle lewenskringe en sirkels of terreine. Hierdie Messiaanse karakter van die kerk hou m.i. daarom baie meer in as wat S. C. W. Duvenage met Christus as die "saambindende faktor van kerk en koninkryk" aandui, wat daarop neerkom dat Christus ,die sentrum van beide" is (a.w., p. 125). Hierdie voorstelling smaak m.i. na 'n dualistiese apriori van kerk en koninkryk as twee soortgelyke groothede. Dit lei tot 'n sisteemdwang en 'n oorvereenvoudigde koninkryk-as-sfeer-begrip waarvan die kerk 'n deel uitmaak. Die filosofies-spekulatiewe plek wat aan Christus as ,sentrum" of "middelpunt" van sirkels toegeken word, hinder my die meeste. Om te sê dat Christus „,saambindende faktor van kerk en koninkryk" is, maak Hom eintlik diensbaar aan verabsoluteerde buite-Hom-bestaande "sirkels" van kerk en koninkryk. Hierdie gedagtegang wat moontlik aan $H$. J. Westerink en Cullman ontleen is, gaan m.i. mank aan 'n betreklik statiese, sfeeragtige koninkryks- en kerkbegrip en mis m.i. die transendentale, teosentriese en Christosentriese karaktertrekke wat in hierdie Bybelse begrippe opgesluit lê. Dit mag selfs lei na die gerealiseerde esgatologie van Dodd.

c. Dinamies. (i) Ridderbos sê ,heerskappy" is die wesenlike betekenis van basileia, terwyl die ruimtelike betekenis heeltemal se- 
kondêr is. God handel en sy krag word verlossend en rigtend geopenbaar. Sodoende het die koninkryk 'n dinamiese karakter. Daar is ' $n$ deurbraak en voor die voleinding is daar geen gearriveerde of statiese punt nie. Dit stel die mens gedurig voor beslissinge."

(ii) In die kerk op aarde, wat so innig verweef is met aspekte soos gehoorsaamheid, regering deur die Woord en Gees, 'n „kom" tot God in die praesens (Joh. 6: 37), 'n proses van val en opstaan, deformasie en reformasie, daaglikse bekering, ens., kom die dinamiese ook sterk na vore. Jesus is besig om die ekklesia te bou op die petra (Matth. 16) en hy gee die universeel-missionêre opdrag as 'n blywende taak in Matth. 28:16-20. Die kerk bestaan nie met die oog op homself nie, maar ook met die oog op 'n taak t.o.v. die nasies in diens van die dinamiese koninkryk." In hierdie dinamiek kan daar dus ook heelwat wisselende situasies ontstaan, bv. soos wanneer in die sendbriewe gehandel word met Godsvolk wat selfs die koninkryk weerstaan. Die basiese verhoudinge kan dus moeilik staties geobjektiveer word. Dit moet altyd weer in respectu Dei betrag en beproef word.

d. Toekomstig. (i) Soos die futura van die saligsprekinge, so preek Jesus die groot komende Eschaton. Die koninkryk is tydeliktoekomstig en universeel-kosmies-toekomstig: wêreldvoleinding, oorwinning oor Satan, opstanding van die vlees, ens. Daarom is die ,afmetingen van het koninkrijk universeel"."

(ii) Die kerk beërf in die groot Eschaton die koninkryk. Die plaaslike kerk as openbaring van die universele kerk op aarde is egter nie toekomstig nie, hoewel haar volheid, haar erfenis, haar toekoms, in die toekoms lê. Daar verval haar huidige wese wat die uitgeroeptes in teenstelling met die ongelowiges plaas en gaan die ekklesia oor in die volmaakte volk van die koninkryk. Waar die koninkryk nou onvoltooid is, dra die kerk egter nou uit homself 'n onvolmaakte karakter.

e. Teenwoordig. (i) Met die eerste koms van Jesus het die futurum van die profesie oorgegaan in die praesens van vervulling van die koninkryk. „Niet in de zin dat men tussen tweërlei koninkrijk zou moeten onderscheiden, dat van heden en toekomst, maar zó dat het ene, grote rijk der toekomst heden is geworden... Het is Het ene grote koninkrijk, het is Het komen Gods tot de wereld tot verlossing en gericht. De toekoms dringt echter a.h.w. in het heden in ...")." Die prediking is die aankondiging en afkondiging van die koninkrijk. ${ }^{*}$ Dit is duidelik dat die ekklesia met hierdie teenwoordigheid van die koninkryk 'n nou verband het, maar kerk en koninkryk mag nie soos Calvyn gedoen het, vereenselwig word nie. ${ }^{\text {*t }}$

(ii) Die Godsvolk is teenwoordig in die wêreld onder die dissipels van Jesus. Hy hou dus reeds organisasie aan hulle voor, bou van die ekklesia op die petra, roep tot verantwoording aan Hom (Matth. 10:1), die sendingbevel Matth. 28:16-20. Dit neem na Pinkster ' $n$ duidelike institutere karakter aan. Die beeld van LiggaamHoof (Ef. 1 en Kol. 1) wys volgens prof. Snyman (i) op die samevatting van gelowiges onder een Hoof, (ii) 'n groeiende organisme, (iii) dit word deur Christus vervul en dit bevat ook (iv) organisasie 
(Ef. 5 : 22-33). Die vergelyking van die kerk met 'n Bruid, die huwelik, bring ons reeds op institutêre terrein en hier het die doop sy plek (Ef. $5: 26,4: 4,5$ ). Die universele kerk is reeds organisasie, instituut. So gaan die Skrifbeelde van die meer dinamiese liggaam (Ef. $1: 22$ v.) vanself oor na die meer statiese gebou (Ef. $2: 20$ ), waarvan Jesus en die apostels deel van bly." Die doop verteenwoordig dus nie net voleinding nie, maar ook die vervulling van die koninkryk en bly skeiding maak ,tussen mensen en mensen. Hij lijft in bij een nieuwe gemeenskap. En deze is die van de gemeente, het volk van de Messias". ${ }^{*}$ Waar die gelowiges universeel en plaaslik liggaam, kerk, volk van God is, kan daar dus nie ander sfere van mense naas die kerk tot die koninkryk behoort nie. Dit sou impliseer dat Christus van twee volke of van verskillende ,volkskringe" Koning is.

Ek verwerp dus die voorstelling van Cullmann wat Duvenage as oplossing gee: „Daar is verskillende konsentriese sirkels waarvan Christus die middelpunt is. Die naaste aan Hom staan sy kerk, waarvan $\mathrm{Hy}$ Hoof is. Dan volg die koninkryk van die hemele, wat meer is as net die geïnstitueerde kerk en wat vergestalt word oral waar Christus as Koning erken word, d.w.s. benewens in dle Christelike kerk ook in die Christelike huis, die Christelike skool, die Christelike universiteit, die Christelike bedryf, ens., ens." (a.w., p. 128). Indien hierdie bewering nie op gerealiseerde esgatalogie in objektiewe ,kringe" berus nie, impliseer dit dat die Godsvolk (kerk) losgemaak is van die Godsvolk in huis, skool, universiteit, bedryf, ens. So 'n voorstelling steun nie op die Skrif nie maar ,tot op sekere hoogte" op Cullmann.

'n Mens besef dat die problematiek enersyds veroorsaak word deur die gevaar dat die lewe in institutêre sin verkerklik word en andersyds is die strewe tog om lewensverbande te ,verkerklik" in die sin dat dit van Godsvolk, of sterker gesê, van Christus, d.w.s. Christelik, moet wees. Vandaar het die eertydse onderskeiding van instituut en organisme t.o.v. die kerk gekom, wat mettertyd gelei het tot skeiding sodat die organisme nie meer kerk was nie.

Hoe ingewikkeld en ineengevleg die fasette van 'n organisme soos 'n liggaam, 'n volk, 'n kerk, is, blyk uit die volgende: „Die plaaslike kerk is nie 'n ander kerk of 'n ander organisasie as die universele nie. Die plaaslike is die algemene wat hom op elke plek organiseer"." „Die onderskeiding van sigbare en onsigbare kerk val nie saam met dié van lokale en universele kerk nie, want die universele het ook 'n sigbare kant, $\mathrm{nl}$. as organisme. Die onderskeiding sigbare en onsigbare Kerk val ook nie saam met instituut en organisme nie, want die universele kerk is ook geïnstitueer in die apostoliese amp..." so Die plaaslike kerk is nie alleen kerk wanneer dit saamkom nie, maar dit is ook kerk wanneer dit juis saam is nie, soos Paulus sê in 1 Kor. 15 : 9: ,Ek het die ekklesia vervolg'; die kerk fungeer plaaslik al is dit nie byeen nie ..". Die universele kerk as organisme tree dus juis in die organisme van die plaaslike kerk aan die lig omdat Hebr. 10:24 aan die gelowiges opdra om op mekaar ag te gee „om tot liefde en goeie werke aan te spoor" of 
volgens 1 Thess. 5: $11 \mathrm{om}$ mekaar te bemoedig en op te bou."

Vanuit hierdie gesigspunt moet $\mathrm{m}$.i. die verhouding van die kerk (Godsvolk) tot ander lewensverbande bepaal word. Die kerk as koning-volk-gemeenskap, Hoof-liggaam-organisme, dryf die Godsvolk individueel, gesinsmatig en in georganiseerde lewensverbande uit om in alle lewensverbande die essensiële Koning-burger-, Vader-kindrelasie te openbaar en te bevorder. So verstaan ' $n$ mens tog Math. $5: 13-16$ en die gelykenis van die suurdeeg. Die kerklike instituut kom dan soos 'n kragsentrale met die oog op die Godsvolk as 'n botydelike maar tegelyk binne-tydelike werklikheid in die boesem van die Godsvolk te staan. Nie die kerk nie, maar die koning-wees van Christus moet d.m.v. die lidmate van en uit die kerk alle lewensverbande deurdring. Dit sluit vir my op die bevinding van prof. Snyman en dr. J. C. Coetzee dat so ook die volk (en per analogie) die menslike gemeenskapsverbande per slot van sake in hulle uitverkorenes, die Godsvolk, die kerk, verlos word.

Dat dit primêr gaan om die koning-wees van Christus in die gewone lewensverbande blyk nog 'n keer uit die tugoefening volgens Matth. 17 : 17 v. Ongehoorsaamheid aan en afval van die koning op terreine buite die instituut moet deur die Godsvolk buite die institutêre mure teëgegaan word en eers by verharding in die institutêre ekklesia (Matth. 18: 17) betrek word. So kan 'n gebeurde op enige lewensterrein weer terugreflekteer in die amptelike samekoms van die Godsvolk. (In hoeverre het ons nie kerk met skool, staat, maatskappy gelykgeskakel, elkeen met 'n eie soewereiniteit en tugoefening, sodat behalwe miskien egskeiding slegs suiwer interne aangeleenthede soos kerkbywoning in die kerk met die Woord van Christus getug word? Raak die kerk nie ten nadele van die heerskappy van God (koninkryk) op 'n terrein ingeperk nie?) Die kerk dra immers die regterlike volmag, die outoriteit (leer en regterlike outoriteit) oor die ingaan in die koninkryk.

„The church as whole has also been spoken of as the ,instrument' of God in this world (h.a. J. C. Hoekendyk: The Church inside out, p. 42-44) and undoubtedly it is the best instrument of the Spirit for the coming of the Kingdom. Now... (the) church of God is represented by church names, church assemblies... but primarily she is represented by people who claim to be its members"." Moontlik dink ons vandag die minste aan hierdie lidmate wanneer ons ,kerk” sê, vandaar die verwarring in kerkbegrip, soos J. H. van Wyk aangetoon het." Uitskakeling van die volk vir die amptelike is moontlik ook die belangrikste rede vir die verswakking van die kerk as openbaring en instrument van die koninkryk.

\section{5. 'n Kritiese aanduiding van enkele gevare in 'n gesekulari- seerde koninkryksbegrip}

In die liberale teologie word vrywel algemeen aanvaar dat Jesus die basileia gepreek het, terwyl die sigbare kerk sy ontstaan in die dissipels, mense, gehad het. Jesus sou dan ook nie in die kerk nie, maar slegs in die innerlike religie van die individu belang stel. Die kerk is gesekulariseer tot 'n gewoon menslike samelewingsverband 
soos staat, skool, vereniging. Vervolgens word die koninkryk ook veelal beskou as 'n religieus-sedelike grootheid, volgens Dodd eintlik gerealiseerde esgatologie, 'n geestelike gemeenskap, 'n maatskaplike orde.$^{3 i}$ Te maklik word daar dan van 'n Christelike staat, 'n Christelike volk, 'n Christelike skool, 'n Christelike aksie gepraat - sonder dat die inhoudelike toets, die dinamiese gehoorsaamheid aan die Woord en Gees van die Koning, aangelê word. Die vraag na die koninkryk (koning-wees) is nie ' $n$ vraag na bedoeling of formele konstitusie nie, maar van daadwerklike onderwerping aan die heerskappy van God.

Ek kon self nie kennis neem van die proefskrif van $H$. J. Westerink in 1937 aan die V.U. oor die Koninkryk van die Hemele nie. Hy het dit opgevolg met artikels, waarvan ook deur S. C. W. Duvenage aangehaal word. Hy maak op grond van eksegese uit Ef. 1 en Kol. 1 skerp onderskeid tussen Christus as Hoof van die kerk en Christus as Koning van ander lewensterreine. Hy beskou dit selfs as 'n teken van gebrekkige onderskeidingsvermoë om (soos die belydenis doen!) van Christus as Koning van sy kerk te spreek. J. Faber het die eksegese van Westerink verwerp en sê: „De Nevenstelling kerkkoninkryk, Hoofd-Koning, welke Westerink poneert, is onjuist"." In die lig van wat ek hierbo betoog het oor die begrip "Godsvolk" is dit m. $\mathrm{i}$. reeds verantwoord om van Christus as Koning van sy kerk te praat. Hoewel dit nie so bedoeld mag wees nie, kan die teenstelling van kerk en koninkryk op horisontale vlak ligtelik lei tot 'n vorm van gerealiseerde esgatalogie soos by Dodd.

In sy proefskrif sê dr. S. C. W. Duvenage: „Die koninkryk van Jesus Christus... kom tot sigbare vergestalting midde in hierdie wêreld en in die tyd. Hierdie vergestalting van die koninkryk vind plaas nie alleen in die kerk nie maar ook in die ander wydvertakte lewensopenbaringe van ' $n$ volk. Uiters belangrik is die vraag na watter plek die kerk en volk inneem in die voorstuwende gang van die koninkryk. En belangrik is ook die vraag na die verhouding tussen kerk en volk. Die een kan die ander naamlik lig in die weg staan in die positiewe taak tot bevordering van die koninkryk".

Hierdie benadering tot die probleem lok dadelik kritiese opmerkings na vore. Wanneer jy, soos aangetoon, volgens die Skrif Godsvolk hierbo vir kerk sou inlees, kry jy òf 'n newestelling ò 'n antitese tussen die Godsvolk en die etniese volk. In alle geval kom dit neer op ' $n$ dualisme tussen kerk en volk en kan selfs as denasionalisering van die Godsvolk (soos bv. t.o.v. rasseverhoudinge in die liberale teologie gangbaar is) vertolk word.

Tweedens wek die kompartementele benadering van kerk en volk, kerk en ander lewensverbande, vraagtekens. In die uitspraak figureer kerk as een teenoor ,ander wydvertakte lewensopenbaringe van 'n volk'. Die kerk lyk dan nie alleen na 'n gewone menslike verband nie, maar ook asof dit ter wille van die koninkryk aanvulling uit ' $n$ menigte ander verbande nodig het. Daarbenewens sou sekere lewensverbande sonder die Godsvolk die koninkryk kon "vergestalt".

Derdens wil 'n mens aanneem dat Duvenage dit nie so bedoel 
nie. Tog kom die vraag na vore of die terme kerk en koninkryk hier in Skriftuurlike en konfessionele sin gebruik word, of is die begrippe filosofies gekleurd? Hoewel Duvenage Kuyper se onderskeiding tussen instituut en organisme ${ }^{i 0}$ afwys, is sy kerkbegrip waarskynlik institutêr beperk en sy koninkryksbegrip gebieds- of terreinbepaald.

Vierdens bevraagteken ek die gedagte dat kerk en volk mekaar in die weg sou staan ,tot bevordering van die koninkryk". Dieselfde gedagte vind 'n mens ook by prof. W. J. de Klerk in 'n rede oor die "Calvinisme". Hy sê ook ,Die koninkryk is breër as die kerk en kerkisme kan juis die uitbouing van die koninkryk versper". Indien ons onder kerkisme dieselfde verstaan, lê die probleem hoofsaaklik by hierdie praktiese ponering van 'n deel van die koninkryk buite die kerk, d.w.s. buite die Godsvolk. Die gevaar loer dan om die deur wanneer De Klerk sê ,die Calvinisme is die formulering van God se Woord" waardeur aan die filosofie feitlik 'n kerklike taak toegewys word; wanneer hy sê „Die Calvinisme as Bybelse Christendom, sal deur die poorte van die hel nie vernietig word nie" en hy dus die Calvinisme in die plek van ekklesia in Matth. 16 : 18 lees; wanneer hy sê: „Die Calvinisme is juis die antwoord vir die toekoms... In hierdie oorlog van idees, val die roeping juis op die Calvinisme om bevel oor te neem (van wie? B.S.), want van alle Christelike lewensbeskouings is die Calvinisme die heldhaftigste ... hanteerders van die Christelike religie ...". Hierdie uitsprake in 'n toespraak is miskien nie so bedoel nie, maar „Calvinisme" as filosofiese struktuur kan op hierdie weg in konkurrensie kom met die Konfessie, die kerk en die koninkryk van God. Laasgenoemde ken tog net een heerskappy, naamlik dié van God deur sy Woord en Gees. Dit is tog één daad, één handeling, één heerskappy van God.

Juis hier behou die kerk as Godsvolk sy unieke plek wat deur geen Christelike Instituut, C.S.V. of A.C.B. oorgeneem mag word nie. Die kerk is diegene wat ,als orgaan van de basileia geroepen worden tot de belijdenis van Jezus als de Christus, tot de gehoorzaamheid aan zijn geboden, tot de missionaire taak... De kerk wordt in allerlei opzicht door de openbaring, door de voortgang, door de toekomst van het koninkrijk Gods omstuwd en gedreven zonder nochtans zelf de basileia te zijn of ook ooit met haar vereenzelvigd te zullen worden...".

\section{Konklusie}

In sy wese bestaan die kerk uit mense wat God tot sy ewige koninkryk gebring het. Tog is die sigbare kerk breër as die koninkryk in so ver dit met hipokriete vermeng is. Die koninkryk is in sy wese die heerskappy van God, verlossend vir sy kerk en gerigmatig vir die ongelowiges. Die heerskappy van God strek egter ook verder as mense. As sodanig is die koninkryk ruimer as die kerk. Die positiewe openbaring van die koninkryk hang gevolglik onlosmaaklik saam met gehoorsaamheid aan die Woord en Gees van God.

(Gelewer voor G.T.V. Pretoria, Augustus 1969).

B. Spoelstra. 


\section{VERWYSINGS}

Tj. van der Walt: Die koninkryk van God - Naby, p. 32 v.

H. J. Jager: Kernwoorden van het N.T., p. 16 v.

G. Kittel: Theol. Wörterbuch zum N.T. I, p. 582.

Herman N. Ridderbos: De Komst van het Koninkrijk, p. 297.

J. Ridderbos: Predikende het Fvangelie des Koninkrijks, p. 227.

N. H. Ridderbos: a.w., p. 290.

7 Ibid., p. 290-291.

8 Ibid., p. 294.

9 Ibid., p. 295.

10 J. C. Coetzee: Volk en Godsvolk in dic N.T., p. 19.

11 H. N. Ridderbos: a.w., p. 309-311.

12 Ibid., p. 318.

13 J. C. Coetzee: a.w., p. 13, vgl. pp. 13, 19, 23.

14 Ibid., p. 41.

15 W. J. Snyman: Die gebruik van die woord kerk in die N.T.

16 Coetzee: a.w., p. 44

17 Kittel: T.W. zum N.T., p. 279.

18 Ibid., p. 581 v.

19 Ibid., p. 583 v.

20 H. N. Ridderbos, p. 25 v., 36, 40.

21 Ibid., p. 307.

22 Ibid., p. 288.

23 Ibid., p. 84, 86.

24 Ibid., p. 307.

25 Kittel: a.w., p. 588.

26 Snyman: a.w., p. 7.

27 H. N. Ridderbos: a.w., p 178.

28 Coetzee: a.w., p. 89.

29 H. N. Ridderbos: a.w., p. 178.

30 Ibid., p. 301.

31 Ibid., p. 152, vgl. 154.

32 Ibid., p. 224.

33 Snyman: a.w., p. 8. Vgl. Ridderbos: a.w., p. 303.

34 H. N. Ridderbos: a.w., p. 325 v.

35 Ibid., p. 318.

36 W. D. Jonker: Om die regering van Christus in sy kerk, pp. 3, 7.

37 J. van Minnen oor art. 11 N.G.B. in Altijd bereid tot verantwoording, p. 70. Vgl. Kat. Antw. 47.

38 Snyman: a.w., p. 38.

39 Jonker: a.w., p. 25.

40 H. N. Ridderbos: a.w., p. 318.

41 H. N. Ridderbos: a.w., p. $41-43$.

42 Ibid., p. 320-324.

43 Ibid., p. 58 v.

44 Ibid., p. 68.

45 Ibid., p. 78.

46 Ibid., p. 289.

47 Snyman: a.w., p. 6-9.

48 H. N. Ridderbos: a.w., p. 335.

49 Snyman: a.w., p. 13. V. E. d'Assonville: John Knox and the Institutes of Calvin, p. 86.

50 Snyman: a.w., p. 11.

51 Ibid., p. 5.

52 Ibid., p. 13.

53 H. N. Ridderbos: a.w., p. 31'1-317.

54 R. Recker: The Church Mission Programme. International Reformed Bulletin, Nr. 25, p. 85.

55 In die Skriflig, Aug.-Sept. 1968, Nr. 7, p. 12 v.

56 Ridderbos: a.w., p. 288. Vgl. O. Linton: Das Problem der Uhrkirche in der Neueren Forschung, p. 157-183.

57 Ridderbos: a.w., p. 53-56. 
58 De Reformatie 2.7 .49 , p. $336 \mathrm{v}$, en 16.7 .49 , p. $355 \mathrm{v}$.

59 S. C. W. Duvenage: Kerk, volk, jeug. Die verhouding van kerk tot volk, p. 13.

60 Ibid., p. 63, nota 117 .

61 Studiestuk nr 33, I.B.C. W. J. de Klerk: Die Calvinisme in Suid-Afrika 'n Toekomsperspektief.

62 H. N. Ridderbos: a.w., p. 308. 